\title{
The Flat Earth satire: using science theater to debunk absurd theories
}

\author{
George Sand França ${ }^{1,2}$, Ricardo Cruccioli Ribeiro ${ }^{3}$, Luana Rosa Soares ${ }^{2}$, João Calmoni ${ }^{2}$, Gabriel B. de França ${ }^{4}$, and \\ Paulo Eduardo Brito 5
}

${ }^{1}$ Observatório Sismológico, Universidade de Brasília, Brasília, 70910-900, Brazil

${ }^{2}$ Faculdade de Artes Dulcina de Moraes, Brasília, 70.392-902, Brazil

${ }^{3}$ Faculdade de Educação, Universidade de Brasília, Brasília, 70910-900, Brazil

${ }^{4}$ Instituto de Química, Universidade de Brasília, Brasília, 70910-900, Brazil

${ }^{5}$ Faculdade Planaltina, Universidade de Brasília, Brasília, 70910-900, Brazil

Correspondence: George Sand França (georgesand@unb.br)

Received: 15 March 2020 - Discussion started: 15 June 2020

Revised: 20 April 2021 - Accepted: 26 April 2021 - Published: 1 June 2021

Abstract. Science needs everyone and everything; therefore, art must be used for its understanding. As the popularity of social media grows, absurd theories have been gaining consensus and, even worse, becoming factual truths without any criticism for many. Thus, aiming to find solutions for a better understanding of our scientific theories, the project "The earth is flat! And, now what?" was created. This project uses performing art as the main communicator to spread science. The first step consisted of calling a meeting to promote integration among the project participants and professionals from different areas of expertise such as geophysicists, art educators, artists, astronomers, and clowns. The meeting was also an occasion for planning the show. The second step consisted of developing the dramaturgy along with the creative process, which involved discussions on scenes and lessons about the theme to be presented, and the third step was the performance. The bibliographical review, the equivalent of the "table's work" for artists, was not based on indexed journals, but rather on social networks and classes for understanding the shape of the Earth. The show impacts the audience in a fun way, offering the opportunity for the general population to experience science in a new way.

\section{Introduction}

Social media environments have enjoyed massive growth recently and, with this, absurd theories are being accepted as science and factual truth while spreading considerably in society. There seems to be no consensus regarding controversial topics such as creationism or global warming and even regarding the shape of the Earth. In Brazil, although the "Big Bang Theory" series was shown for general audiences on $\mathrm{TV}$, the scientific dissemination is mostly limited to children while paying no attention to the adult audience. Academia sometimes engages in some actions, but without a wide reach and with low popularity. The search for a connection between science and art is certainly complicated, due to the exhaustive scientific activity of researchers, who are not able to present themselves as artists or art-related most of the time. One of the best options to bridge this gap is to invite educational artists and more colleagues in the sciences to work together. To this end, the theatrical play "The earth is flat! And, now what?" (in Portuguese: A terra é plana! E agora?) was created and first shown at the General Assembly during the European Geoscience Union (EGU) 2019 (França et al., 2019a), followed by five performances in theaters. This play won the DF 2019 Theater Award Category: Local Circulation Show. The play uses a clown to explain the whole process of creation, connecting science and art while applying our research to improve the understanding of the audience of the topic at hand. Suspendisse a elit ut leo pharetra cursus sed quis diam. Nullam dapibus, ante vitae congue egestas, sem ex semper 
orci, vel sodales sapien nibh sed lectus. Etiam vehicula lectus quis orci ultricies dapibus. In sit amet lorem egestas, pretium sem sed, tempus lorem.

\section{Art-science and the process}

Palma (2006), in his experience with the art and science project on stage, reports that, although theater is a powerful tool for disseminating scientific principles, implementing this integration is permeated with difficulties. This project won several awards and had great repercussions in the community. The dialog between science and theater is old; however, it is still a localized movement with little material available, especially in Brazil. Among the experiences in Brazil, Almeida et al. (2018) presented their successful and continued project for integrating science and theater at the Museu Ciência e Vida (Museum of Science and Life) in Duque de Caxias-RJ. On the other hand, our work focuses on the Earth sciences field and art, which are still very little explored. Firstly, several pieces of information on the flat Earth subject were collected from the groups found in the social networks defending this point of view and news refuting this theory; after that, the scenes were created. In the show, the introduction scenes are based on Mamulengo, which is the Portuguese name given to the puppetry theater, also known as marionettes and/or puppets. Culturally, it is one of the richest popular spectacles of northeastern Brazil, in which a dramatic representation using puppets is played on a small elevated stage covered by a curtain to hide the people/actors giving life and lending their voices to the characters. Depending on the play's nature, the puppets are handled by hand, stick, metal stick, or string (Gaspar, 2021). This first scene introduces Dr. Terremoto (Dr. Earthquake), the show's protagonist, which is followed by a short lecture showing at least three slides. In the next scene, a text about the big bang theory was adapted from Oliveira (2019), recorded, and presented as a choreography. After that, Dr. Terremoto sings a song written by Thomazoni (2013), which was inspired by the opening of the "Big Bang Theory" series. Also, scenes from França et al. (2019a) (Fig. 1) featuring Newton and gravity based on the fall of the apple myth presented in the EGU session are shown. This scene is followed by the story of the planets, which are represented with balloons and a Pilates ball, based on the film "The Great Dictator" by Charlie Chaplin and, finally, the "Earth is Flat" speech.

The scenes' creative process lasted about 6 months while being evaluated weekly during the rehearsals. The costume worn by the storyteller actor consisted, initially, of a black suit with red details and checkered pants, which were later replaced by brown shorts and coupled with wine-colored socks, a white shirt, and suspenders to complete the costume. The idea behind the storyteller costume was to pepper it with some clown props. The dramaturgy was a compilation of the scenes described above and was then improved and adapted
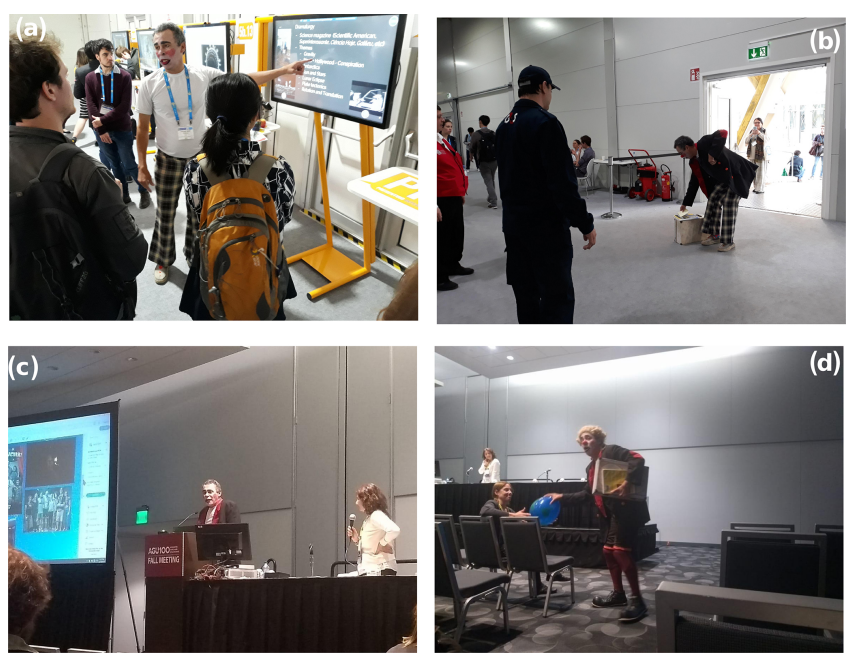

Figure 1. (a) The first presentation at the EGU 2019, where it all started. (b) Arrival at the EGU 2019 congress in Vienna. (c, d) AGU fall meeting 2019 in San Francisco.

during rehearsals. After that, we held an open rehearsal, in which local artists and scientists were invited to talk and discuss the show before its premiere. After the play itself was ready, we had to plan for a practical scenario that was easy to move around, so we chose a folding screen, a pulpit, a ball, and a transport crate.

Overall, the play was shown two times at different times of the day during international conferences (França et al., 2019a, b) and seven times in theaters to an audience of 316 people considering only the seven theater performances. The presentations took place at the following venues: the FAP-DF on 12 October; Casa dos Quatro from 15 to 17 November; Oficina Perdiz from 21 to 22 December; and participation at the FICA festival of Casa da Ribeira in the city of Natal$\mathrm{RN}$ on 29 December. The presentation posters and photos are shown in Fig. 2.

\section{Results}

The audience was invited to evaluate the performances by filling out a previously handed Google form consisting of nine questions and an optional comment that was available to every audience member. Of the 316 people who watched the show, only $11 \%$ answered the questionnaire. This low number of respondents is probably because, in Natal, where we had the largest audience, the questionnaire was available only after the last performance, whose audience consisted of several known people and friends. Nevertheless, the questionnaire answers steered us toward several reflections on both the artistic point of view and scientific dissemination.

Figure 3 shows the histogram of the responses and the audience. The questionnaire responses were given by audience members who watched the shows as follows: about $40 \%$ at 


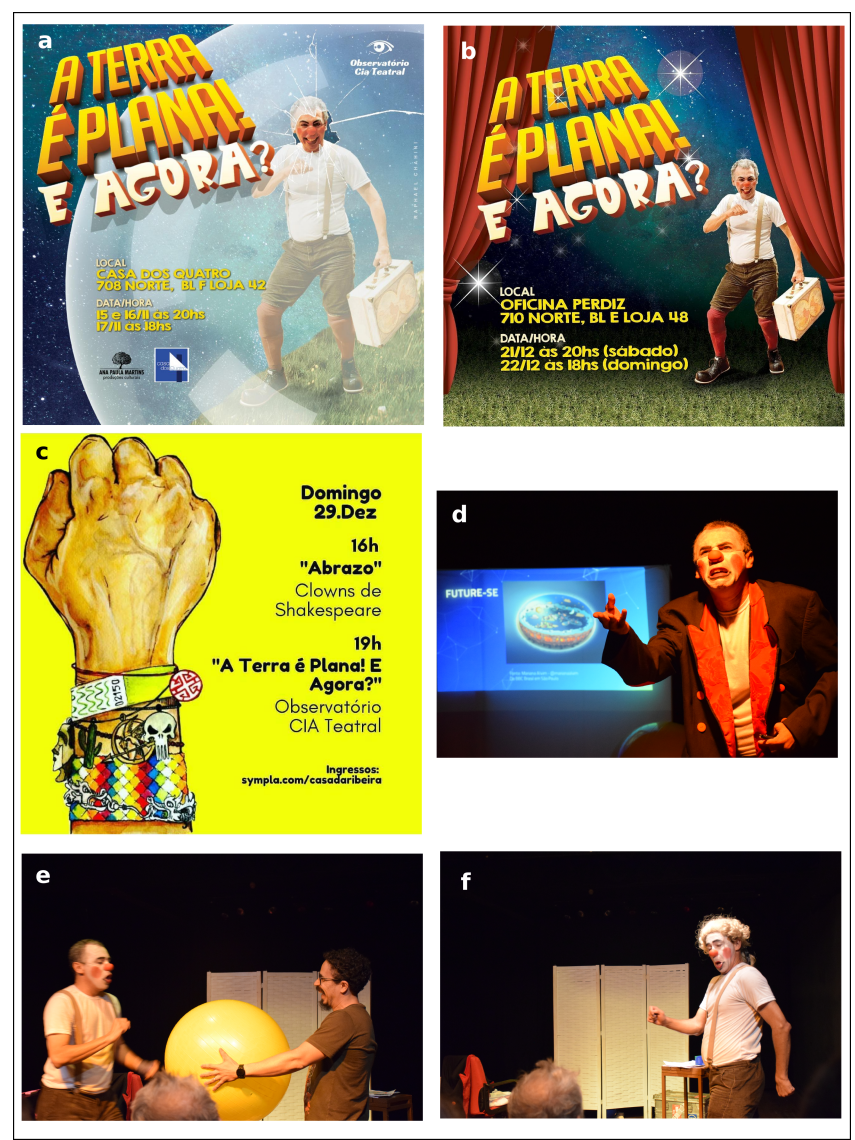

Figure 2. The posters of the shows that took place in Casa dos Quatro (a), Teatro Oficina Perdiz (b) and Casa da Ribeira (c); and photos $(\mathbf{d}, \mathbf{e}, \mathbf{f})$ taken during the play by Hugo de Freitas.

Casa Ribeira in Natal-RN, followed by $37.1 \%$ (three shows) and $25.7 \%$ (two shows) at Casa dos Quatro and Teatro Oficina Perdiz, respectively, in Brasília. Therefore, the responses were well distributed among the show audiences, which also included professionals from academia during the presentation held in Natal-RN. The more diverse audience in Natal was because the play was presented during a theater festival, FICA, which presented the first review of the play by the collective Farofa critics. This review is available only in Portuguese on the Farofa Critica website (Costa, 2021).

The majority of the public, $82.8 \%$, had a high degree of understanding of the Earth's shape, and, certainly, the title makes the public more aware of the subject (Fig. 3a). The number drops when the question is a little more specific; however, it is well discussed in high school. Furthermore, $69.6 \%$ of the public knew about the law of universal gravitation (Fig. 3b). In the last question on heliocentrism, $20 \%$ of the respondents did not know what it was (Fig. 3c). The results directed us to believe that the audience had excellent knowledge of the subject, whose understanding was apparent given the audience's laughter during the play.

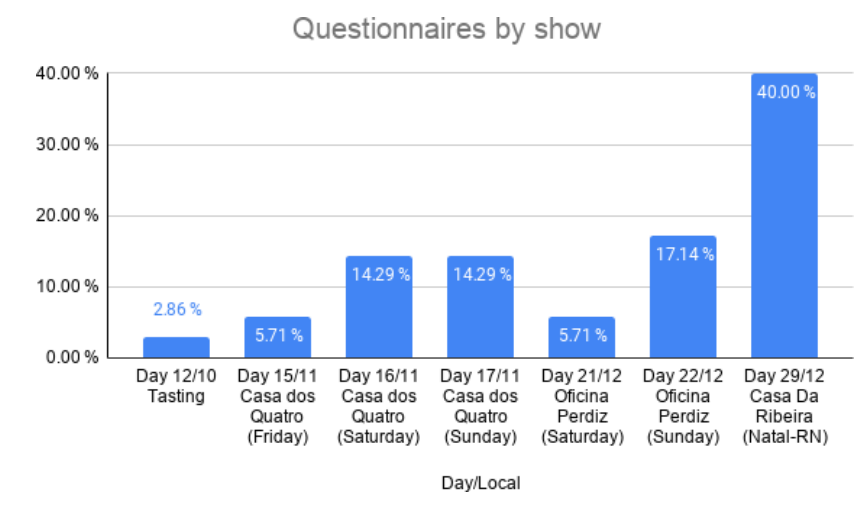

Figure 3. Histogram of audience and responses.

The second part of the questionnaire concerned scientific dissemination and had, among the questions, one that asked the respondents to associate one word with the play they just watched. Figure 4 shows a word cloud highlighting the answers of the audience describing the show as didactic, interesting, fun, playful, and genial, thus showing the play's general acceptance by the public. The next question asked the audience to score the play between 1 and 5 (low to high dissemination) regarding science dissemination; $83 \%$ gave scores of $4 \%$ and $5 \%$, and $17 \%$ gave a score of 3 , showing again the importance of this play used at least in the Federal Capital of Brazil (Fig. 5).

Furthermore, only $40 \%$ became even more curious regarding the Earth's shape: this is because the vast majority of the audience were aware of the Earth's shape and certainly did not believe that a flat Earth surface is feasible (Fig. 6).

The overall score results indicate that $80 \%$ of the audience assigned scores 4 and 5, thus recommending the play to other viewers, similarly to the scores assigned to scientific dissemination. Therefore, it can be concluded that the play was well received by the public (Fig. 7).

The general comments about the play highlight that the show is not completely ready yet, especially the end of the play; questions the reason for using "mamulengos"; and the issue of the flat Earth and the physics speech. Another comment about the play regarded the actors' training and qualification in the field of sciences. Finally, all comments are going to be used for updating the play and trying to present the best show.

\section{Discussion and conclusion}

Creating a play is a long and arduous process, but when it was finally presented we realized it is an excellent way of informing and publicizing the subject at hand. The public who, for the most part, had prior knowledge of the subject took into account the scientific dissemination nature of the play and considered it an excellent show. The show had a good 
(a)

How well do you understand the shape of the Earth?

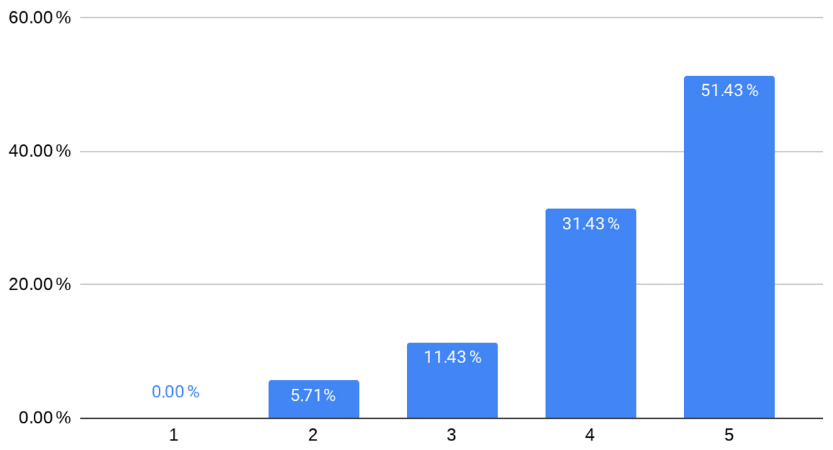

Understanding of the law of universal gravitation

(b)

$$
80.00 \%
$$

$60.00 \%$

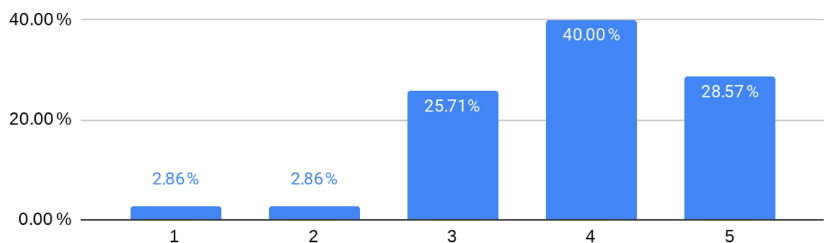

Understand Heliocentrism.

(c)

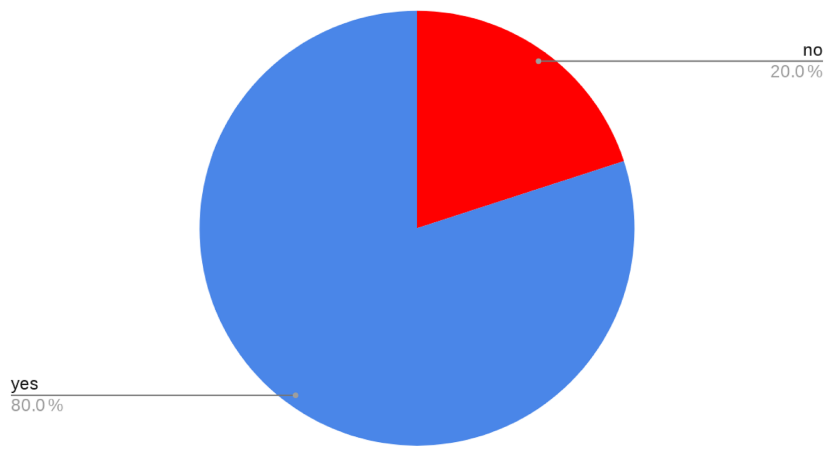

Figure 4. Graphics (a) "what do you understand about the shape of the Earth?", (b) "what do you know about universal gravitation?", and (c) "what is heliocentric?"

reception in the local community, winning the DF 2019 Theater Award Category: Local Circulation Show.

The importance of disseminating sciences using art as a tool opens a popular space for science while also presenting shows to a new kind of audience that is not frequent in this space. The possibilities for exploring this path are endless, but still, few come to fruition. We need to connect art and science, aiming to strengthen both education and art, which

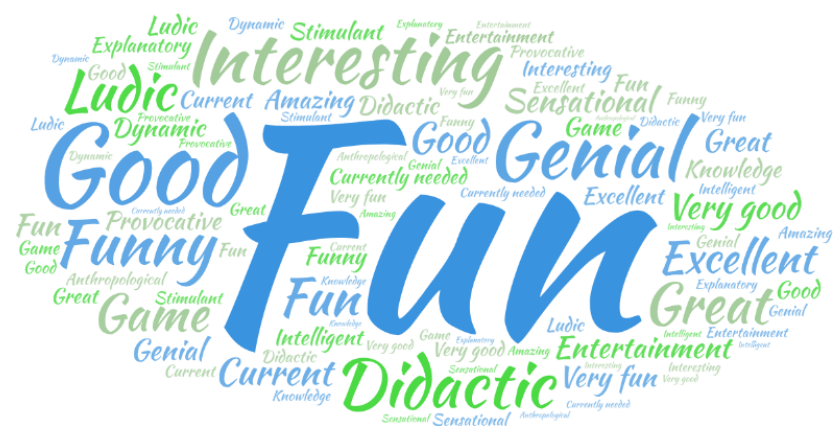

Figure 5. The word cloud shows the main words linked with/describing the play.

Do you think this show promotes science?

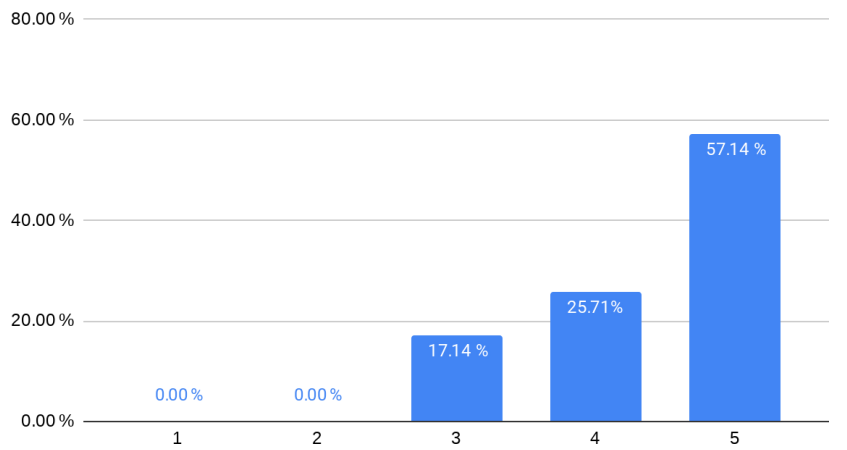

Figure 6. Plot showing the percentage of people agreeing that the play promotes science.

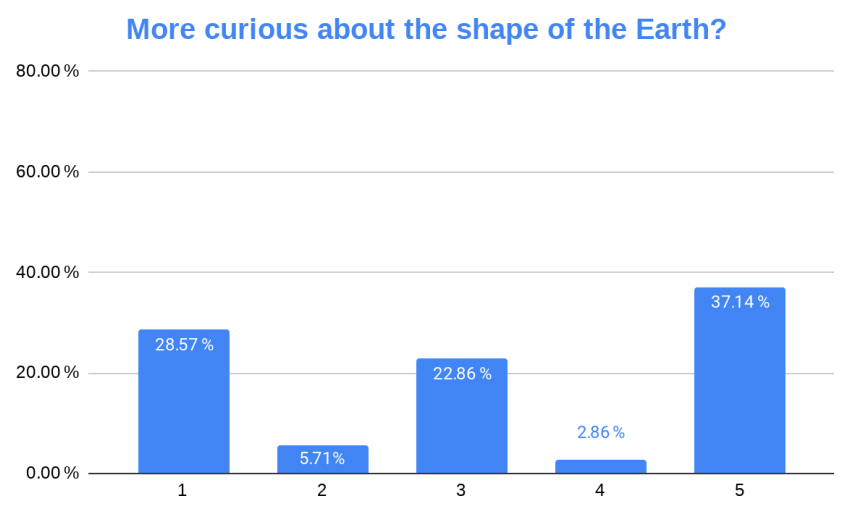

Figure 7. Plot showing the percentage of people more curious about the shape of the Earth.

together should further guarantee the quality of scientific dissemination. In addition, researchers should embrace scientific dissemination as an important role played by scientists and participate as collaborators in most dissemination activities. By participating in these activities, explaining well their role in society while establishing the connection between science and art can make science and knowledge more popular, stimulating and boosting science in all areas. 
You would recommend the show

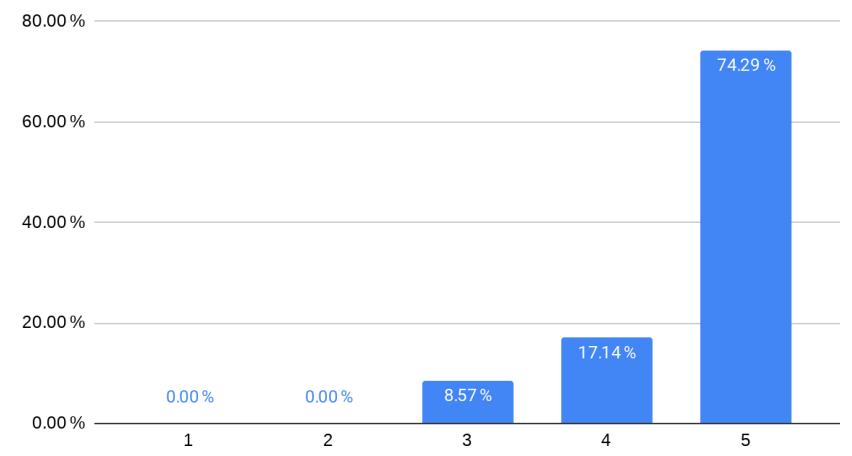

Figure 8. Plot showing the audience percentage recommending the play.

The next steps are to present the play in public and private schools, to tour Brazil, and to invite more undergraduate students to participate in this project.

Data availability. The data used for this study are available at https://drive.google.com/file/d/ 15GOUitaQbLJIJczMyDaW1YCnmaXocX_x/view?usp=sharing (França et al., 2021).

Author contributions. The project was conceived, designed, and implemented by GSF, RCR, LRS, JC, and GBF. PEB supervised the concepts of astronomy. All the authors contributed to the preparation of the article.

Competing interests. The authors declare that they have no conflict of interest.

Special issue statement. This article is part of the special issue "Five years of Earth sciences and art at the EGU (2015-2019)". It is a result of the EGU General Assembly 2019, Vienna, Austria, 7-12 April 2019.

Acknowledgements. We are thankful to Hugo Freitas and Lyanna Soares for the photos. George Sand França thanks CNPq for the PQ grants.

Financial support. This study was financed in part by the CAPES - code 001.

Review statement. This paper was edited by Francesco Mugnai and reviewed by Juliana Garrido Damaceno, Aleksander Väljamäe, and one anonymous referee.

\section{References}

Almeida, C., Bento, L., Jardim, G., Freire, M., Amorim, L., and Ramalho, M.: Ciência e teatro como objeto de pesquisa, Ciência e Cultura, 70, 35-40, https://doi.org/10.21800/231766602018000200011, 2018 (in Portuguese).

Costa, Q.: O que fazer com esse cheiro de terraplanista, available at: http://www.farofacritica.com.br/festivais/conteudo/137/ o-que-fazer-com-esse-cheiro-de-terraplanista, last access: 10 April 2021 (in Portuguese).

França, G. S., Ribeiro, R. C., Soares, L. R., Soares, J. O., and Brito, P. E.: The process of creation of theatrical show for scientific divulgation, EGU General Assembly 2019, Vol. 21, EGU20196085, 2019a.

França, G. S., Ribeiro, R. C., Soares, L. R., Soares, J. O., and França, G. B.: Theatrical show for scientific divulgation, AGU Fall Meeting 2019, ED23B-06, San Francisco, CA, USA, 2019b.

França, G. S., Ribeiro, R. C., Soares, L. R., Calmoni, J., de França, G. B., and Brito, P. E.: Feedback do espetáculo - A Terra é plana! E agora?, data, https://drive.google.com/file/d/ 15GOUitaQbLJIJczMyDaW1YCnmaXocX_x/view?usp= sharing, last access: 26 May 2021.

Gaspar, L.: Mamulengo Puppetry. Pesquisa Escolar On Line, Joaquim Nabuco Foundation, Recife, available at: https: //pesquisaescolar.fundaj.gov.br/en/artigo/mamulengo-puppetry/, last access: 26 May 2021.

Oliveira, A. J.: Do Big Bang até você em um minuto: uma brevíssima história do Universo, Revista Galileu, available at: https://revistagalileu.globo.com/Ciencia/Espaco/noticia/2018/03/dobig-bang-ate-voce-em-um-minuto-uma-brevissima-historia-douniverso.html, last access: 20 December 2019 (in Portuguese).

Palma, C.: Art and science on the stage, História, Ciências, SaúdeManguinhos, 13, 233-246, https://doi.org/10.1590/S010459702006000500014, 2006 (in Portuguese).

Thomazoni, W.: A historia do universo - lyrics available, available at: https://soundcloud.com/wagnerthomazoni/ historia-do-universo (last access: 26 May 2021), 2013 (in Portuguese). 